\title{
"THIS IS NOT A CAKE RECIPE": HISTORICITY AS AN ELEMENT FOR THE UNDERSTANDING AND TRANSFORMATION OF A WASTE MANAGEMENT ACTIVITY AT A UNIVERSITY HOSPITAL IN BRAZIL*
}

\author{
Maurício Donavan Rodrigues Paniza** \\ Marcio Pascoal Cassandre ${ }^{\text {***k }}$
}

doi: 10.11144/Javeriana.ca031-57.tcrhe. Research paper. Received: 01/06/2018. Accepted: 14/11/2018. Cite as: Rodrigues Paniza, M. D., \& Cassandre, M. P. (2018). "This is not a cake recipe": Historicity as an element for the understanding and transformation of a waste management activity at a university hospital in Brazil. Cuadernos de Administración, 31 (57), 45-77. http://dx.doi.org/10.11144/Javeriana. ca031-57.tcrhe

* * PhD in Business Administration, Fundação Getúlio Vargas (EAESP-FGV), São Paulo, Brazil, 2017. Associate Professor of Universidade Estadual de Londrina (UEL), São Paulo and Londrina, Brazil.

E-mail: mauricio.paniza@fgv.edu.br / mauriciopaniza@gmail.com

*** PhD in Business Administration of Universidade Positivo (UP), Curitiba, Brazil, 2012. Assistant Professor of Universidade Estadual de Maringá, Maringá, Brazil and Copenhage, Dinamarca.

E-mail: mcassandre@hotmail.com 
"This is not a cake recipe": Historicity as an element for the understanding and transformation of a waste management activity at a university hospital in Brazil

“Esta no es una receta de tarta": la historicidad como elemento para la comprensión y la transformación de una actividad de gestión de residuos en un hospital universitario de Brasil

"Esta não é uma receita de bolo": a historicidade como elemento para a compreensão e a transformação de uma atividade de gestão de lixo em um hospital universitário do Brasil
ABSTRACT. This article analyzes the potential of interventions based on historicity for organizational learning. Intervention methodologies that include the exploration of past executions allow projecting future changes in an activity. A study of the Change Laboratory on the waste management activity was carried out with a group of 20 workers from different areas in a university hospital in Brazil. After 12 intervention sessions based on three types of historicity (history in movement, history of memory recovery and history to build the present), participants perceived that the organization of the activity had been insufficient to meet the demands of the hospital and society. The present historicity in the learning experience allowed participants to be aware of themselves and the importance of waste management. This process occurred both from a functional and a social point of view. Likewise, the study revealed the rejection of the participants towards ready recipes for waste management in their hospital.

Keywords: Expansive Learning, Change Laboratory, Waste Management. JEL Codes: M12, M54, Q53

RESUMEN. Este artículo analiza el potencial de las intervenciones basadas en historicidad para el aprendizaje organizacional. Las metodologías de intervención que incluyen la exploración de las ejecuciones pasadas permiten proyectar cambios futuros en una actividad. Un estudio de Laboratorio de Cambio alrededor de la actividad de gestión de residuos fue realizado con un grupo de 20 trabajadores de diferentes áreas en un hospital universitario en Brasil. Luego de 12 sesiones de intervención basadas en tres tipos de historicidad (historia en movimiento, historia de recuperación de la memoria e historia para construir el presente), los participantes percibieron que la organización de la actividad había sido insuficiente para atender las demandas del hospital y de la sociedad. La historicidad presente en la experiencia de aprendizaje permitió que los participantes tomaran consciencia de sí mismos y de la importancia de la gestión de residuos. Este proceso se dio tanto desde el punto de vista funcional como social. Igualmente, el estudio reveló el rechazo de los participantes hacia recetas listas de gestión de los residuos en su hospital.

Palabras clave: Aprendizaje organizacional, laboratorio de cambio, gestión de residuos. Códigos JEL: M12, M54, Q53

RESUMO. Este artigo analisa o potencial das pesquisas baseadas em historicidade para a aprendizagem organizacional. As metodologias de intervenção que incluem a exploração das execuções passadas permitem projetar mudanças futuras em uma atividade. Um estudo de Laboratório de Mudança ao redor da atividade de gestão do lixo foi realizado com um grupo de 20 trabalhadores de diferentes áreas em um hospital universitário no Brasil. Após 12 sessões de intervenção baseadas em três tipos de historicidade (história em movimento, história de recuperação da memória e história para construir o presente), os participantes perceberam que a organização da atividade tinha sido insuficiente para atender as demandas do hospital e da sociedade. A historicidade presente na experiência de aprendizagem permitiu que os participantes tomassem consciência de si mesmos e da importância da gestão do lixo. Este processo deu-se tanto desde o ponto de vista funcional quanto do ponto de vista social. Igualmente, o estudo revelou a rejeição dos participantes por receitas prontas de gestão para o lixo no seu hospital.

Palavras chave: aprendizagem organizacional, laboratório de mudança, gestão do lixo. Códigos JEL: M12, M54, Q53 


\section{Introduction}

The discourse that the world is changing very rapidly is deep-rooted in our society. The Fetish of Change, as Grey (2004) calls this omnipotent presence of such a change is nothing more than the result of the very action of men in organizations, so it is not the organizational environment that changes at a frenetic pace, but is itself men's work in organizations that generates this change. Being just a jargon present in society, that we live times of unprecedented changes due to world is changing at an ever-faster rate or that change is a consequence of human action, what is questioned is how the changes affect the daily organizational context and cause significant influence in certain environments. Because of that, managers need to develop skills such as innovation, flexibility, resilience, agility, and the ability to reevaluate strategies, in order to reformulate methods and/or to adapt the administrative processes.

Recipes and prescriptions to generate changes and updates are sold as immediate saviors to organizations that are involved in crisis contexts. However, in this frenetic quest for change and practical recipes, we question whether what has been learned and now needs to be changed is valued as an element of creation of the new. More directly, the question is: how historicity from the Change Laboratory intervention based on the Cultural-Historical Activity Theory (CHAT) can be used as a methodological resource for organizational learning?

Our inspiration about historicity is the work of the Belarusian Lev Semyonovich Vygodsky, in which the last name now is used as Vygotsky. He was born in 1896 and died in 1934 is the main name of the call historical-cultural psychology that focused his studies on the human nature of the twentieth century. Grounded on dialectical-historical materialism, these studies were intended to understand psychological development as a historical process. For him, the psychological functioning is based on social relations, which, in turn, develop and are produced within the culture and in a historical process (Braga, 2010).

Lev Vygotsky was an important and expressive theorist of twentieth-century psychology who contrasted with the naturalistic, mechanistic, and idealistic understandings of the time and admitted the presupposition of the social constitution of psychic processes. In his understanding, human development is produced in history and culture in processes of signification. His grounding in Marx and Engels on consciousness establishes the understanding that the origins of higher forms of conscious behavior should be pursued in historically formed social conditions of life (Vygotsky, 1978). In this sense, the aspects 
considered essential in the constitution of the psyche and important in the theoretical elaboration on human development for Vygotsky (1978) are culture and history. For him, it is within the culture and historical process that social relations, which provide basis for psychological functioning are generated.

For Vygotsky (1978), human action does not occur directly and immediately in the social world, but through the indirect mediation of signs, instruments and others. For him, it is within the culture and historical process that social relations, which provide basis for psychological functioning are generated. Not only in the direct use of an instrument, not even for the immediate use as perceived in the animals. The human mediation that Vygotsky understands is the one planned and prepared for future use, consciously, manmade to carry out his work collectively. Inspired by materialist dialectical philosophy, Vygotsky (1978) created the idea of cultural mediation of human action, whose concept became central to the Activity Theory.

When it comes to history, Levitin and Davydov (1982, p. 44) point out that Vygotsky considered Marxist psychology as the only scientific psychology. In their opinion, contrasting those authors who had lost their sense of historicity and demanded that psychology "break with the past" and "make a new beginning," Vygotsky alleged that change of psychology on the basis of Marxism did not in any way mean cancelling all preceding work. Each strength of free thought to gain insight into the psyche and every attempt at deterministic investigation were preparing a future psychology and therefore would necessarily be incorporated into it in an adapted form. Similarly, the expansion of a socio-economic development in Marxist doctrine, so the advance of the psyche must be viewed as a natural historical process.

Vygotsky concentrated his studies on the concepts of children's development, assigning an extensive critique of the understanding of the authors of his time on the role of development, learning and maturation, since, for him, children's learning begins long before they already have a previous history at that moment, that is, an accumulated knowledge that cannot be ignored. Studies of Vygotsky and his neuropsychology research fellows such as Alexander Luria and Alexei Leontiev Nikolaievich underlie what is now the areas of Psychology, Education and Organizational Studies call Activity Theory, or what has been called lately “Cultural-Historical Activity Theory” (CHAT).

The Activity Theory began with studies on the development of children and expanded to studies of various work activities mainly based on Vygotsky. The main idea of this theory 
is to consider an activity historically in development as the theoretical unit of analysis (Engeström \& Miettinen et al., 1999). By the time the historical perspective became more visible to the Organization Studies, the CHAT, whose ontological basis relies on the historical-dialectical materialism and on the Russian psychology, had already considered it as a seminal construct to understand the relation between humans and organizations (Engeström, 1987). In this work, we reflect upon historicity through an organizational experience based on the interventionist methodology of the Change Laboratory (CL, from now on), applied to the waste management at a university hospital in Brazil.

The Change Laboratory was created in Finland and has been applied to learning experiences worldwide. According to this methodology, for a change to happen, apprentices need to reconstruct historically the activity through a dialogue between past ("how we worked"), present ("how we work now") and future ("how we want to work"). This methodology is relevant insofar as it considers historicity, or the movement that the object (in this case, the hospital waste) performed or performs throughout the organization lifecycle. The Change Laboratory attempts to provide apprentices with the ability to reconstruct and reconceptualize work activities (Sannino et al., 2016). To do so, workers are meant to have the possibility of acting as agents of the reality they are supposed to change (Haapassari \& Kerosuo, 2015; Vänninen et al., 2015; Haapasaari et al., 2018). Bearing this in mind, the researcher - aiming for being a facilitator of such process - plays the role of an interventionist researcher inside the reality studied, such as a teacher would do.

There are several theories that try to understand the organizational learning process, a fact that makes this a polysemous subject (Antonello \& Godoy, 2011). However, Engeström (2001) points out that not all of those theories understand the learning process as something dynamic - which means that people need to learn how to deal with fast and efficient changes in their activities. The CHAT aims at sending light to this discussion by contemplating, through histories, the learning that emerge from the transformations experienced by human beings in their activities (Querol et al., 2011; Cassandre, 2012; Engeström, 2014; Sannino et al., 2016).

In order to facilitate the learning process of participants, the researcher makes use of some theoretical-methodological artifacts during the Change Laboratory intervention. Within the concept of cultural mediation, the relation between the subject and the object is mediated by cultural artifacts, such as signs and tools. According to Cole (1996), an artifact is defined as an aspect of the material world that has been modified through- 
out the history of its constitution through actions focused on a directed objective. An artifact is both material and ideal (conceptual). For example, a pen is both a material object and the embodiment of a human idea of the function of a pen. There can be no artifact without these two characteristics, the material and the ideal. This is also true of words, for no word exists without its material support. The main theoretical concept used in this process is the double stimulation (Vygotsky, 1978). According to it, the first stimulus is previously given, i.e., the problem to be faced, which needs transformation. The second stimulus corresponds to artifacts offered to the workers (participants) by the interventionist, which help them with the search for the historical contradictions/ disturbances that hinder the development of the activity (Engeström et al., 2011). Similarly, possible alternatives are given to face such contradictions and transform the activity into one the workers consider the best.

However, since the workers are the agents in the expansive learning process, the materialized learning may not be positive at all times (Rantavuori et al., 2016). In other words, the materialized learning is subjected to the historical, cultural and reflexive movement constructed by the intervention participants. Also, regarding the expansive learning, the study does not consider great transformations as a start point. Instead, a germ cell is taken into consideration - a small fragment of the organization that presents the problems lived by it in a large scale (Cassandre, 2012).

Twenty workers from different hierarchical levels (management, technical and operational levels) undertook the reconstruction of the history of a waste management activity held at a university hospital. The Change Laboratory intervention used the activity system as unit of analysis (Engeström, 2014), which is a triangular graphic representation that includes central analytical elements for pondering about the past, present and the future of the activity. These elements are: participant, instruments, rules, community, and work division. All of these elements under analysis are seen by the apprentices (participants) through the perspective of the activity object, that is, the purpose of such activity.

The participation of hospital workers in the $\mathrm{CL}$ intervention occurred throughout 12 sessions, of which two focused on the monitoring and individual interviews with eight participants to know what their perceptions were about the learning experience that they had just undergone. The sessions lasted about two hours and took place between August 2015 and 0ctober 2016. Eight individual interviews were conducted in 0ctober 2016. In parallel to the development of a past activity system, another artifact was developed: a timeline of the waste management activity. 
From that perspective this study contributes to the area of organizational learning in the sense that it brings an international approach relatively new to Latin America context. It also contributes to the Brazilian social context since it proposes an intervention at a university hospital, which in this case is an extension of a public university, and counts on the participation of department members as well as technical and operational workers from the institution. In terms of theory, this paper is in dialogue with the Interventional Methodologies in which brought to Latin America the debate about Organizational Learning that portrays the historical and cultural reality of workers and the specific reality of our organizations, whose differences are striking when compared to the place of its origin, the Europe. The transposition work of Interventional Methodologies for Organizational Learning, started in 2011 in Brazil, has advanced significantly as you build learning experiences through the use of Change Laboratory meta-tool (Querol, Jackson-Filho, \& Cassandre, 2011; Querol, Cassandre, \& Bulgacov, 2014; Santos, 2017).

Besides this introductory topic, this paper presents an explanation about the theoretical artifacts of the study, which involve the use of the $C L$ as a method for the expansive learning - as termed by the CHAT. Afterwards, it presents the Methodological Artifacts that guided the construction of the study and the CL historical path containing the movement of expansive learning specifically related to the waste management activity. This is followed by the discussion about the findings of this study and the final considerations.

\section{The Change Laboratory as a method to the expansive learning}

The interventionist methodology of the Change Laboratory emerged in the 1980s, influenced by the Finnish researcher Yrjö Engeström who made efforts in the CHAT to change social practices. It was precisely in 1982 that an informal group of activist researchers was created in Finland to develop various types of research into various types of human resource development practices. In addition to Engeström, this group included Ritva Engeström, Kirsti Launis, Rejio Miettinen, Kari Toikka, and Jaakko Virkkunen (Sannino et al., 2009).

The CL was inspired by the Developmental Work Research (DWR), created in the 1970 s as a result of the collaboration between workers and researchers - Finnish as well - whose methodology assumed that "the historical-analytical study of work is related to the practical-experimental approach, that is, to the actual transformation of the work" (Cassandre, 2012, p. 125). The CL is the name given to a set of concepts and methodological principles that can be used in collaboration between researchers and professionals for 
deep transformations or incremental superficial transformations at work. The method used in $\mathrm{CL}$ is based on concepts and understandings derived from CHAT.

Engeström (1987) explains the CL's method based on de Zone of Proximal Development (ZPD) of Vygotsky. For him, the learning should be related in some way with the child's developmental level. In his understandings the introduction of the teaching of writing, reading, and arithmetic must begin at a certain age, but this determination must be reconsidered when one intends to discover the current relationships of the development process and learning capacities. Of course, when Vygotsky wrote about ZPD he was subsidizing concepts for his understanding of child development. The ZPD has been transposed to the understanding of adult development in work environments as foreseen in the DWR. Nevertheless, their initial explanation of the interaction between people in mediated environments is an important understanding for the correct transposition of the method into organizational studies.

Understanding the existence of the development of a child's mental abilities only when she responds to tests autonomously and competently is challenged by Vygotsky. He suggests other ways of knowing the mental development of a child, such as stimulating the initiative to solve a certain task promoted and informed by the teacher in collaboration with others and, even if there is some flaw, valuing this initiative considering there was some development. The classical view of psychology attests that only the child's independent activity in problem solving offered by tests indicates his mental development, thereby neglecting the existing potential in helping others, such as teachers and other participants in a school environment can favor in the child's learning.

Vygotsky proposes that an essential characteristic of learning is the creation of the ZPD, that is, learning can awaken a variety of internal development processes that are able to function only when a person is interacting with others in their environment and in cooperation with their peers. In order to solve a problem, people make use of cultural artifacts, which accumulate human knowledge through history. By using these tools, people become more independent of the immediate context and open up new possibilities for future development, making them proactive agents (Meshcheryakov, 2007).

Engeström (2000) explains that the DWR method constructs the Zone of Proximal Development (ZPD) of a given activity. The ZPD represents the distance between what one currently knows and what one can possibly know in the future with the help of an experienced person. When applied to the organizational context, the ZPD of the organization 
becomes an obscure area situated among: 1) the actions incorporated in the current activity, which has a history of its own, and contradictions; 2 ) the planned activity, wherein the contradictions are expansively solved; and 3) the planned activity, in which the contradictions led to the contraction as well as to the destruction of opportunities.

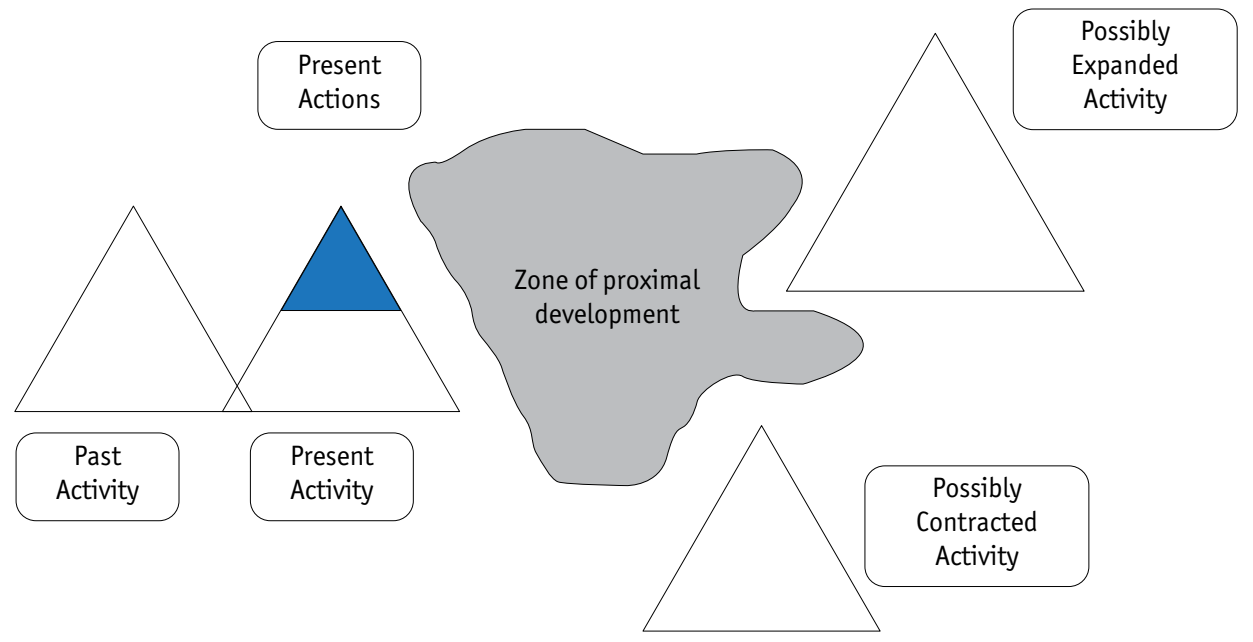

Figure 1. Zone of proximal development according to the developmental work research Source: Adapted from Engeström (2000, p. 157).

As stated by Engeström (2000), even though the ZPD presupposes a movement for the expansion of the activities, the process of reconceptualization takes place through processes that involve conflicts and relations of power, and whose advances are negotiated by a workgroup. In this attempt to expand the activity, there may be dissonant voices that require an internal negotiation; also, the relations between the activity and the external world must be taken into consideration as well.

The theoretical central basis of the CL intervention is the Vygotsky's double stimulation concept. In the formative intervention of the Change Laboratory, workers are faced with a problem-situation that acts as the first stimulus. The second stimulus comes from the work of an interventionist researcher, i.e. someone who bears the pedagogical role of stimulating these workers to the possibly appropriate secondary artifacts (created by the workers themselves or not). Such artifacts can assist laborers to put into practice their agency power to change the problem-situation as well as to develop the activity under analysis (Vygotsky, 1978; Engeström et al., 2016). 
Through the double stimulation method, the organization of the Change Laboratory can supply two needs of the study. The first refers to the discursive element, since what is said by both participants and interventionist researcher works as the second stimulus that can provide a purpose for acting and trigger initiatives. In other words, the $\mathrm{CL}$ participant can become aware of the current work situation and thus find alternatives to overcome the disturbances by using the tools offered by the CL. The second need refers to the instruments shaped by the workers during the intervention process, which are also able to enhance the process for organizational change.

The movement towards the reconceptualization of a work activity aimed by an interventionist study under the CHAT is represented by a cycle of expansive learning, shown in Figure 2. However, this representation is not a clockwise linear process - yet the chart may allow this interpretation. Indeed, the existence of a work cycle is rather a heuristic characteristic than a nomothetic one, since each intervention reality will respond according to the environment proposed and analyzed by the workers. This emphasizes the genetic-historical perspective within CHAT methods, which is interested in understanding the work activities as histories in movement. Besides that, workers will seldom wish to undertake the complete cycle, or even be able to do so.

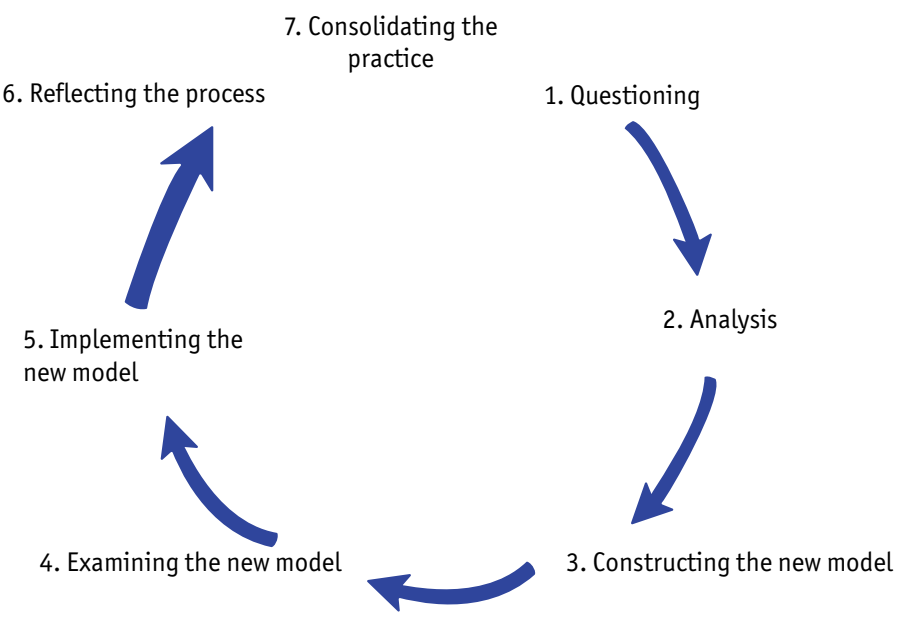

Figure 2. The expansive learning cycle

Source: Adapted from Engeström (2014).

In a Change Laboratory, as Virkkunen and Newnham (2015) advocate, the collectively constructed learning occurs in six phases that are in line with the expansive learning 
cycle, as follows: 1) mapping of the situation: it starts with the workers' realization that the work activity needs to be changed, and that their engagement to do so is a consequent necessity; 2 ) analysis of the situation: workers revisit the past to know how they used to perform their activities, and reflect about the present, thus being aware of the contradictions that hinder their work nowadays; 3 ) creation of a new model: workers prospect the desired activities to be implemented within five years; 4) concretization and test of the new model: workers prospect a change attempt to occur within one month; $5)$ implementation of the new model: workers take the first steps towards the change they planned; 6 ) distribution and consolidation: workers become multipliers of the new theoretical conception of work and translators of the new practice.

Expansive learning refers to situations in which people have created, in a collective way, a new object for their activity, that is, they engage in a change working to overcome a contradiction that is leading the activity to a crisis situation. In order to expand the object of the activity, the subject also needs to create new tools and forms of social organization of the work around this new object. Engeström and Sannino (2010) point out that Expansive Learning implies the conception and implementation of a new concept of activity, which involves the reconstruction of all the elements within an activity system. Expansive learning is a long process of transforming a collective activity. Each step of the process leads to the emergence of a new internal contradiction in the activity, which creates a new learning challenge for practitioners. The expansion of the object requires a way of understanding the internal contradictions of the system and of finding possibilities to continue to develop it. In order to grasp its essence, the subject must understand the logic of its development, and this is possible through the analysis of its historical formation, the existing contradictions and the ways of overcoming / solving this contradiction.

Additionally, it is important to highlight that the Change Laboratory process precedes the first contact between interventionists and workers, as dialogues with the representatives of the client-organization as well as an ethnographic process are necessary for the interventionists to understand the initial reality of the intervened place.

One of the stimuli used by the interventionist researcher to trigger the participants during the $C L$ sessions was the graphic representation of the activity system proposed by Engeström (2014). Inspired in Vygotsky, this representation encompasses a system that, in sum, broadens the possibilities for understanding a given activity by gazing social, 
historical and cultural elements in the macro and microsocial contexts that are part of this very same activity. The elements that embody this system are described in Figure 3.

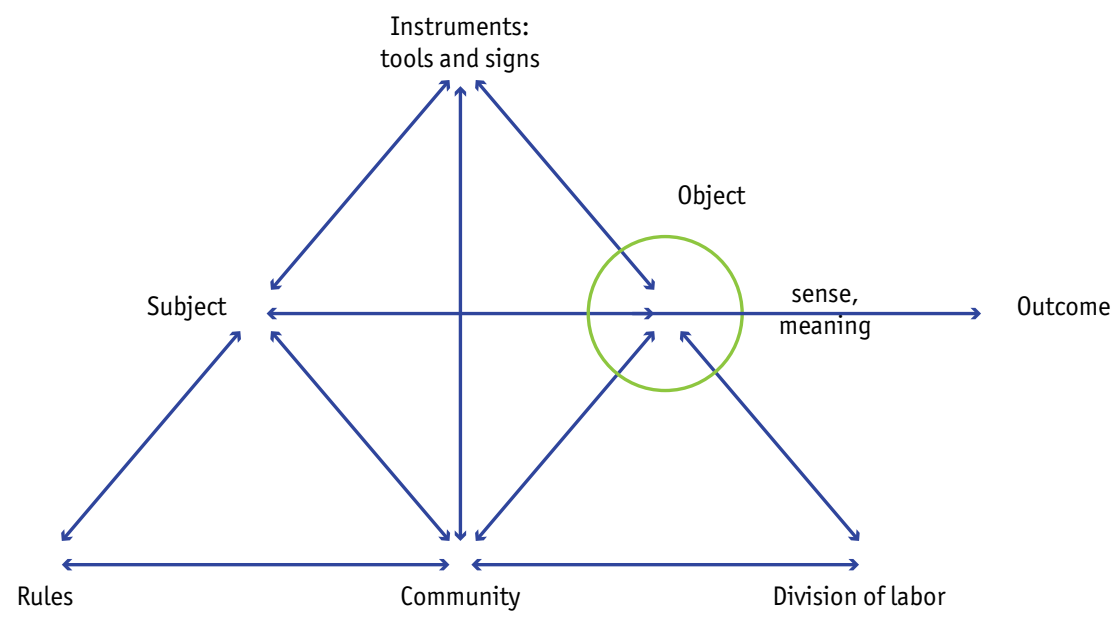

Figure 3. Engeström's activity system

Source: Adapted from Engeström (2014).

In this representation, participants are the people who compose the intervention process, since their viewpoints must be considered in the analysis of the situation. Object refers to the motivation and finality of the activity, considering the fact that it is not a stable element, inasmuch as the people involved in the intervention process can make different interpretations of identical events. Tools are instruments that physically or symbolically mediate workers' actions. Community refers to the group of people that share the same activity object. Work division refers to the distribution of the activities, which are crossed by hierarchical and power relations, as well as by "conflicts, acts of resistance and status". Finally, rules are the regulatory or legal elements that can be either a plus or an obstacle to the development of the activity object; indeed, they signal the actions of the people involved in the activity (Cassandre, 2012, p. 78).

Historically, there are tensions between the elements of the activity system. Because of that, and in order to learn through the expansive perspective, the group need to try to overcome these contradictions, which "are considered the matrix force of the transformation, helping to put the object in motion" (Querol et al., 2014, p. 410). Engeström (2014) remarks that the activity's contradictions emerge from the shock between individual actions and the collective social system in which the activities are inserted. Additionally, 
the author posits that the means by which these contradictions are materialized depend on the social and productive conditions inherent to each specific society. Engeström and Sannino (2011) observe that managers do not see the activities' contradictions from a historical point of view, but rather as a present and particular event in the action of organizing. The $\mathrm{CL}$ method helps workers to understand the historical contradictions between the elements of the activity system, so they (workers) can try to construct a new model to this activity.

In summary, the CL intervention methodology involves data collect about: $i$ ) the nature of the problems; ii) the needs to be changed; iii) historical analysis of the activity to determine the dimensions of the development of the activity; iv) the identification of the contradictions; v) set up a new model to cope with the contradictions found; vi) put into practice the new model on a small quantity for future spread the model in all activity. Based on these six steps the method has potentiality to deal with complex problems across one or more organizations so as to work out solutions to many different cases. One of the cases brought by the literature on CL methodology is the reorganization of the division of labor in the postal service of Finland: The work of letter distribution went from individual to teamwork (Engeström et al., 1996).

Another example comes from the work of reorganization toward a specialization in areas according to technologies in telecommunications services in Finland: the creation of new quality development methods and installation services. (Ahonen et al., 2000) A third explanatory case was CL developed to facilitate collaboration between the government and the apple industry in New Zealand by creating groups committed to testing new ways of working, improving service quality and product (Hill et al., 2007). The formation of new concepts and the creation of collaborative tools between teachers and IT professionals in Botswana school for the development of joint pedagogical objectives (Virkkunen \& Tenhunen, 2010) also add to the illustrative cases about CL's potentialities. More recently a health and home care learning process was generated when the implementation of a mobility agreement to maintain physical mobility of home care clients was created in Finland, changing how home care professionals deal with older clients' mobility habits (Kajamaa \& Schultz, 2017).

\section{Methodological artifacts: The construction of the study}

The study was constructed as of the historical path of the CL creation in the hospital between 2013 and 2016, which resulted in a group of 20 workers from different areas 
(technical, operational and higher education professionals) who participated in 12 sessions for the use of the $\mathrm{CL}$ method. The objective was to proceed with a qualitatively transformation of the waste management process, whose findings will be exposed later in this paper.

\section{Table 1}

\section{Characterization of the Change Laboratory participants}

\begin{tabular}{llc}
\hline \multicolumn{1}{c}{ Name $^{1 /}$} & \multicolumn{1}{c}{ Position } & Working years \\
\hline Ana & Administrator & 41 (university), 22 (hospital) \\
Francisca & Nursing Assistant & 23 \\
Marcia & Operational Assistant & 26 \\
Carlos & Operational Assistant & 6 \\
Antonia & Operational Assistant & 21 (university), 15 (hospital) \\
Adriana & Operational Assistant & 14 \\
Jose & Operational Assistant & 14 \\
Antonio & Operational Assistant & 14 \\
Juliana & Operational Assistant & 6 \\
Francisco & Operational Assistant & 7 \\
Fernanda & Operational Assistant & 18 \\
Patricia & Biochemist & 7 \\
Amanda & Nurse & 9 \\
Vanessa & Nurse & 10 \\
Camila & Nurse & 10 \\
Julia & Chemical Engineer & 18 (university), 5 (hospital) \\
Luciana & Nursing Technician & 10 \\
Mariana & Laboratory Technician & 10 \\
Paulo & Administrative Technician & (university), 6 (hospital) \\
Pedro & Laboratory Technician & (university), 5 (hospital) \\
\hline The & &
\end{tabular}

1/ Those are fictitious names.

Source: Own elaboration.

As of the methodological construction, the study was based on the documental analysis of the interventionists' research reports and the audiovisual material wherein the 12 sessions are fully recorded. The documental research was necessary to reconstruct, describe and interpret the social movement that has begun sometime in the past. In this study, the definition of document is borrowed from Cellard (2012), to whom they 
are testimonial registers of past moments. The documents used in this study are private property of the interventionist who coordinated the $\mathrm{CL}$, the client-organization, and the hospital. Regarding ethics, all of the owners previously allowed the access to these documents.

The use of video in social research is discussed by Loizos (2008). The author argues that images - including those with movement and sound, such as videos - can serve as primary data source since they register life events. Thus, this concept considers the materiality and actuality that videos preserve. In addition, Garcez et al. (2011) recommend a category analysis when working with videos in a qualitative research. The idea is to work through the categorization of the audiovisual material collected and with further interpretation on that.

In order to construct the analysis of this article we proceed as follows: $i$ ) we revise the videos already generated in the $C L$ sessions to analyze speeches, dialogues, verbal and gestural expressions that give indications of the existence of manifestations about the history of the subjects of the activity and in the activity, as well as the history that the hospital had for the constitution of the waste management process until the moment of the research; ii) we revisited a timeline graphic constructed (first orally and after written) together with the participants in order to make a selection of moments that could help to find fragments of learning by the historicity; iii) we reexamined the expansive learning cycle designed to the waste management activity following its steps: 1) questioning; 2) analysis; 3 ) construction of a new model; 4) exam of a new model and 5) implementation of the new model.

This third analysis using the expansive learning cycle was made by reading the data created looking for meaning units, trying to figure out what data tells us in terms of themes, ideas expressions, speeches, dialogues, and interactions about moments and situations that would make explicitly a situation of learn right after the participants had recovered past moment located in the history to make the present situation meaningful. After that we order the data in particular themes because they were part of our retelling the story about learning by recapturing the history. The organization of the units showed us three elements of history and learning more often present in raw directed related and interconnected: 'history in movement, 'history by recovering the memory and 'history to build the present'. 


\section{History in movement}

The Change Laboratory experience was firstly proposed in 2013. The negotiation between the university hospital and the researcher lasted until June 2014, when an agreement was finally reached for the research conduction, followed by the elaboration of an intervention plan.

A previous observation in the place where a study is conducted is presumed as the first step of an intervention research according to the methods based on the CHAT. Thus, the interventionist and a team of assistant researchers conducted a participant observation in the place under study. This phase helped the researcher in having a historical and cultural understanding of how the waste management was being conducted at that time. The researchers used hospital uniforms in order to pass unnoticed and maintain secrecy about their identities.

As of the findings of the ethnographical observation held in July and October 2014, the researchers pointed out the disturbances identified in the waste management activity. The possible causes of these disturbances were inadequacies of work tools, such as: inappropriate bins; lack of knowledge about the correct disposal of several materials, and even the intentional incorrect disposal - as a way for expressing discontent with the work procedures prescribed by the hospital. Workers reported that they ignored the ones who would benefit from the properly disposal of the waste (which could be destined to recycling or definite discard); they believed their individual work would make no difference to the final process.

Later on, the interventionist formatted a proposal to the training sector of the hospital about the use of the Change Laboratory method. The triage counted on 24 workers, of which 20 formed the group that participated in the CL sessions. The planning for the 12 sessions is reproduced in Table 2.

The sessions were held in the second semester of 2015 on a weekly basis, and lasted two hours approximately. However, according to the $\mathrm{CL}$ method, a session should not last too long because the apprentices may detach themselves from the historical immersion they are experiencing. The immersion is important to the following meeting because it can elicit a future idea about the reorganization of the activity analyzed. 


\section{Table 2}

Planning for the sessions of the Change Laboratory in the hospital

\begin{tabular}{|c|c|}
\hline Session/Week & Content \\
\hline $1^{\text {st }}$ & $\begin{array}{l}\text { Presentation of the team responsible for conducting the } \mathrm{CL} \text {; explanation about the } \\
\text { dynamics of the } \mathrm{CL} \text { work; discussion about the mirror-data that concerns aspects of the } \\
\text { workgroup's daily practice - observation findings; questioning and problematization of } \\
\text { these practices. }\end{array}$ \\
\hline $2^{\text {nd }}$ & $\begin{array}{l}\text { Continuation of the analysis on the disturbances and constant problems of the mirror- } \\
\text { data. }\end{array}$ \\
\hline $3^{\text {rd }}$ & $\begin{array}{l}\text { Historical data collection conducted by the participants about the waste management } \\
\text { system of the hospital. }\end{array}$ \\
\hline $4^{\text {th }}$ & $\begin{array}{l}\text { Data collection and discussion about the changes on the activity system of the university } \\
\text { hospital. }\end{array}$ \\
\hline $5^{\text {th }}$ & $\begin{array}{l}\text { Continuation of the historical data collection; beginning of the construction of the past } \\
\text { activity system. }\end{array}$ \\
\hline $6^{\text {th }}$ & $\begin{array}{l}\text { Collection of additional data about problematic areas; } \\
\text { Construction of the present activity system. }\end{array}$ \\
\hline $7^{\text {th }}$ & Cataloguing of present contradictions. \\
\hline $8^{\text {th }}$ & $\begin{array}{l}\text { Development, elaboration and evaluation of ideas for a new model as of experiences } \\
\text { shared by members and found in other hospitals. }\end{array}$ \\
\hline $9^{\text {th }}$ & Delineation of the future vision about the activity. \\
\hline $10^{\text {th }}$ & $\begin{array}{l}\text { Presentation of the workers to the hospital director and confrontation with them; } \\
\text { beginning of the collective elaboration of the experimental plan for the new model } \\
\text { implementation; organization of the experiment. }\end{array}$ \\
\hline $11^{\text {th }}$ & $\begin{array}{l}\text { Continuation of the plan's production; } \\
\text { Presentation of the experimental plan. }\end{array}$ \\
\hline $12^{\text {th }}$ & Planning and implementation of the germ cell and follow-up. \\
\hline $1^{\text {st }}$ Follow-up (FU) & Balance of the actions for the germ cell implementation. \\
\hline
\end{tabular}

Source: Interventionist's data (2016).

The $\mathrm{CL}$ sessions began with the first activity of the cycle of expansive learning, what here represents the movement, that is, the questioning of the activity. The apprentices were invited to interview their co-workers so the latter would reveal what dissatisfactions they identified concerning the problem-situation related to the waste management. The data collected from the apprentices and interviewees composed the panels elaborated by the interventionist to show the so-called mirror-data. This terminology refers to the fact that the data show both the data concerning the interventionist's observation and the results of the conflicts noticed by the workers and their co-workers/interviewees. Therefore, at this initial moment of the $\mathrm{CL}$, the apprentices were assisted by the constructed artifacts (namely, interview and mirror-data), which means that they made 
use of the double stimulation for the construction of a Zone of Proximal Development related to the waste management activity.

\section{Table 3}

Comparative of the problem-situation about the waste management activity noticed by the apprentices

\begin{tabular}{|c|c|}
\hline CL participants & Coworkers/Interviewees \\
\hline $\begin{array}{l}\text { Insufficient amount of the time set for waste } \\
\text { collection }\end{array}$ & $\begin{array}{l}\text { Insufficient engagement of workers with proper waste } \\
\text { disposal }\end{array}$ \\
\hline Incorrect disposal of waste & $\begin{array}{l}\text { Plastic bags containing the waste are extremely } \\
\text { heavy, and the distance between the collection point } \\
\text { and the waste disposal points is huge }\end{array}$ \\
\hline Insufficient guidelines for proper disposal of waste & Insufficient training (corporate education) \\
\hline Insufficient points for proper waste storage & Insufficient formal and reliable guidelines \\
\hline $\begin{array}{l}\text { Unplanned structure for the waste management } \\
\text { activity }\end{array}$ & Lack of proper infrastructure to do the activity \\
\hline $\begin{array}{l}\text { Huge distance between collection point and waste } \\
\text { disposal points }\end{array}$ & Steady flow of people \\
\hline $\begin{array}{l}\text { Exposure of materials to contamination (alcohol } \\
\text { oilcans) }\end{array}$ & $\begin{array}{l}\text { Work is performed simultaneously with ongoing } \\
\text { customer/patient service }\end{array}$ \\
\hline $\begin{array}{l}\text { Workers' lack of engagement with proper disposal of } \\
\text { waste }\end{array}$ & Reluctance to dispose waste properly \\
\hline \multirow[t]{3}{*}{ Waste of administrative material } & $\begin{array}{l}\text { Workers would rather dispose the waste in the closest } \\
\text { bin than in the proper one }\end{array}$ \\
\hline & $\begin{array}{l}\text { Ignorance about proper disposal of the waste, and/ } \\
\text { or omission towards the information given by co- } \\
\text { workers about the issue }\end{array}$ \\
\hline & Considerable use of not reusable work tools \\
\hline
\end{tabular}

Source: Interventionist's data (2016).

Bearing in mind the problem-situation pointed out by the workers, the interventionist confronted this data with the mirror-data that refers to the observation made in the first historical moment of the intervention at the hospital. This moment - of comparing the interventionist and their team's findings with those of the workers - marked the end of the activity-questioning phase, which took place between the second part of session 2 and the first part of session 3. After the end of session 2, the interventionist proposed the following task: the participants were supposed to bring someone - a veteran co-worker, for example - that could talk about the history of the waste management activity in the working environment. The completion of this task marked the transition to the second phase of the cycle of expansive learning, that is, the activity analysis. 
The transition to the analysis phase was marked by the investigation of the historical constitution of the waste management in the hospital. In order to reconstruct this path, the CL participants invited two experienced co-workers, a man and a woman, who were informed about the development of the activity since the hospital foundation, in 1989. Besides that, the apprentices were challenged to research on the history of the activity through the Constitution of Brazil as well as through state and local regulations that approach the issue.

Considering the movement represented by the expansive learning cycle during the activity, workers' memories led them to realize that, although there are conflicts in the present, there were conflicts in the past as well, which in fact were attempts to improve the waste management activity. For example, plans to manage waste were elaborated in the past amid law pressures about waste management. Through this analytical-historical perspective, the $C L$ participants were introduced to the activity system and were able to construct the past activity system, pointing out its contradictions.

\section{History by recovering the memory}

A pointed in the Figure 4, the recovery of the historical memory of $C L$ participants enabled them to reflect on the existence of tools and signs that they themselves constructed to deal with the problems they faced at the beginning of hospital activities. As for the instruments, they refer to the Pilot Project initiated, the trainings created to explain the new demand presented by the Pilot Project, and an initial rule for the segregation of waste produced in the hospital activities. The element Subject in the Activity System indicated not only the WMG, but also other entities involved in the activity, such as the agencies that regulated public health issues and the hospital's internal and external community. The Rules were determined mainly by the Federal Constitution, the National Environmental Council-CONAMA and other rules, statutes and laws of the Brazilian State. Participants mentioned for Community that public institutions are interested in the correct collection, mainly interested in public health, as well as the individual collectors who expected the correct segregation working to collect the possible materials to be recycled in turn to obtain personal income. The Division of Labor was determined by the WMG's own hierarchy as well as the hospital community.

The red rays represent the situations wherein participants found historical tensions related to the contradictions of the activity. It is important to mention that in this study, the contradictions marked by red rays are not object of analysis. 


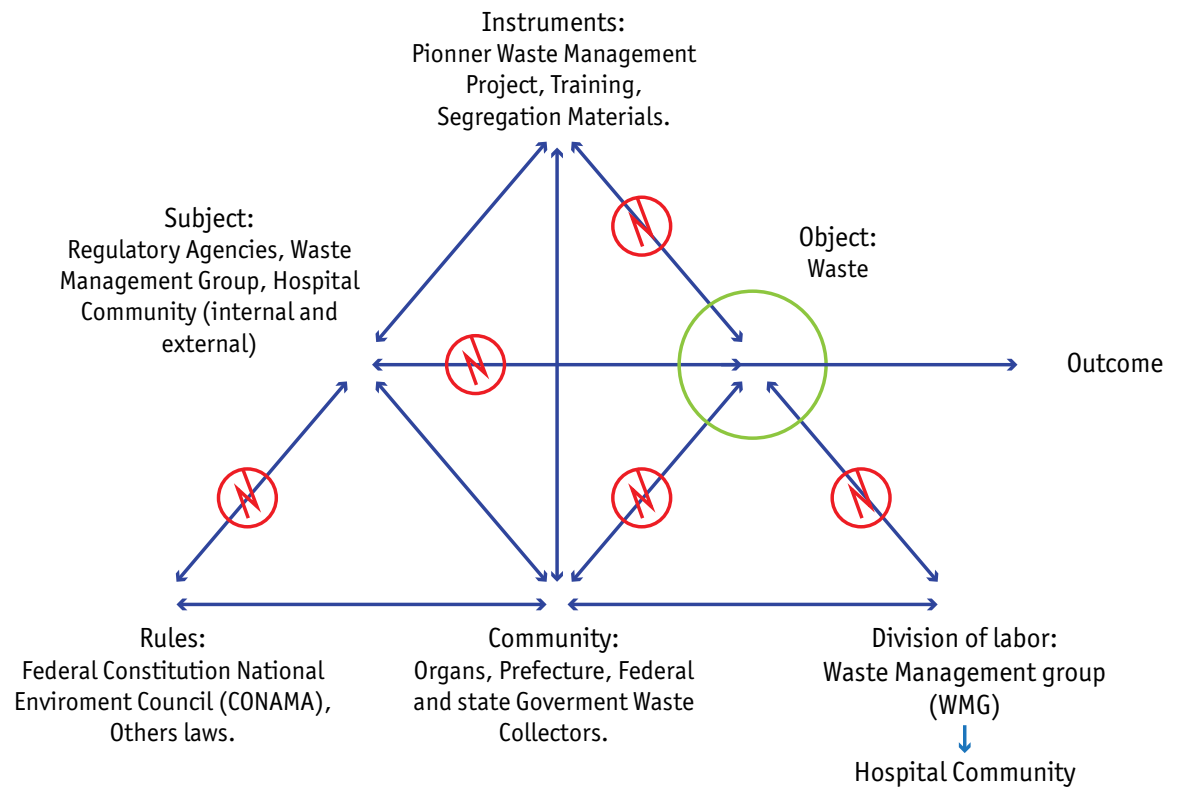

Figure 4. Past activity system

Source: Research data (2016).

After the construction of the past activity system by recovering the memory, the interventionist led the group to reflect about the existent contradictions. During session 6 , in which the elements of the activity system met the past contradictions, the CL group moved on to the analysis of the present activity. It is important to highlight the dialectical movement that marks this activity, i.e.: to analyze the present situation, the interventionist drew the participants attention to the fact that at that very moment they were supposed to bring back the elements for questioning the activity that had been brought to light in the beginning of the CL. The first present elements, added to the past ones, were put under discussion so the outcome would possibly be a collective construction that responds to the following question: how did we work today? The response to such question was turned into the present activity system, as presented in Figure 5.

\section{History to build the present}

The present Acticity System reflected by the participants indicated that the changes comparing to the past Activity System were more about the Instruments (tool and signs) than the Subject, Rules, Community and Division of Labor. As for the Instruments of the 
present, there were booklets informing about segregation, packaging, and disposal of waste by type and risk of contamination. The booklets were used during a kind of training called "ambiance", a tool created to standardize the ways to segregate, pack and dispose of the waste generated by each sector of the hospital. Tags named by "labels" were produced to be fixed on the top of the bins' lids. Attempts to standardize materials to landfills were created. New bins replaced the old ones. The replacement of collection carts that were not suited to the activity, exchange containers was necessary. The creation of a temporary shelter to receive the waste was another solution made. Instruments (tools and signs) not created officially by the WMG but necessary to the actual demands were pointed out. Although there are occasional problems, the instruments of work proved historically were more adequate in the present time, as a result of the very work carried out by the pioneer (mentioned in the past) WMG.

Instruments:

Booklets, labels, dumpsters, new stands, new materials, improvised instruments, improvised temporary shelter, ambiance.

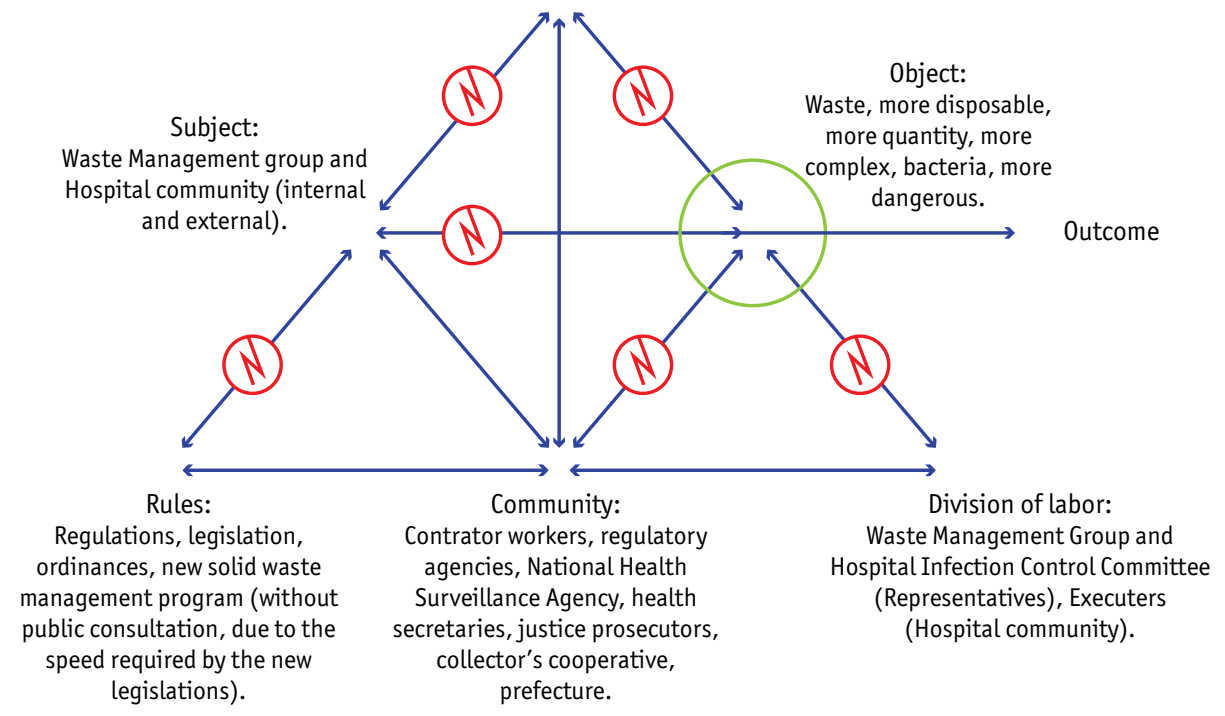

\section{Figure 5. Present activity system}

Source: Research data (2016).

Having constructed the past and present activity systems, and identified the contradictions of each system, the workgroup concluded the movement of the activity analysis phase, realizing that the activity had become more challenging and complex. The 
transition to phases 3 and 4 was conducted through a task given by the interventionist when the group finished phase 2 .

The participants were challenged to get inspired by similar organizations in order to outline a model for the activity they would like to implement in the future. To do so, workers were stimulated to visit other hospitals so they could see which solutions these institutions had found for the waste management. This task aimed at unveiling, firstly, the similarities (if there was any) between the solutions found by these hospitals and the ones found by the university hospital. Also, the apprentices were supposed to notice how the hospitals' solutions could serve as a model to the activity the group was going to construct. Following this, the dialectical exercise consisted of speculating about the existent models found through the data analysis of the former phase. This exercise resulted in a collective outline of the future action towards the activity.

The initial suggestion to reorganize the activity was the creation of a new group to be in charge of the waste management. According to the apprentices, the group would give courses and clarify doubts about the issue. Then, the interventionist conducted the apprentices to reflect on the reorganization of that structure. To perform session 10, the workgroup invited the hospital director that agreed with the workers' reorganization proposal. Thus, the learning model was put into action, and the new model proposed that: there should be a waste management comitee, who was supposed to be autonomous and include an employee working in a full-time basis. Still in session 10, the apprentices outlined the plan for the implementation of the new activity model.

The Change Laboratory participants also had to decide on the place where this reorganization proposal would be initially tested, that is, the place where the germ cell would be implemented. Together, apprentices decided on four segments of the hospitalization sector (Pediatrics, General Practice, Surgery, Gynecology and Obstetrics), since they were places where most of the workers were permanently placed. Also, these segments were chosen because they were representatives of the problems faced by the hospital in general, as well as for their small size and interconnection.

With the help from the hospital's high management team, the workgroup moved on to phase 5 , that is, the implementation preparation. In this phase, workers constructed the activity system of the waste management aimed for the future. 
It is important to mention the perspective of "contradictions absence", which is materialized by the absence of the red rays. Ideally, contradictions were solved through the workers' effort towards changing and reorganizing the activity.

Instruments:

Booklets, Enviroment sensitization, Communication media, Segregation materials, Temporary shelter, Indicators.

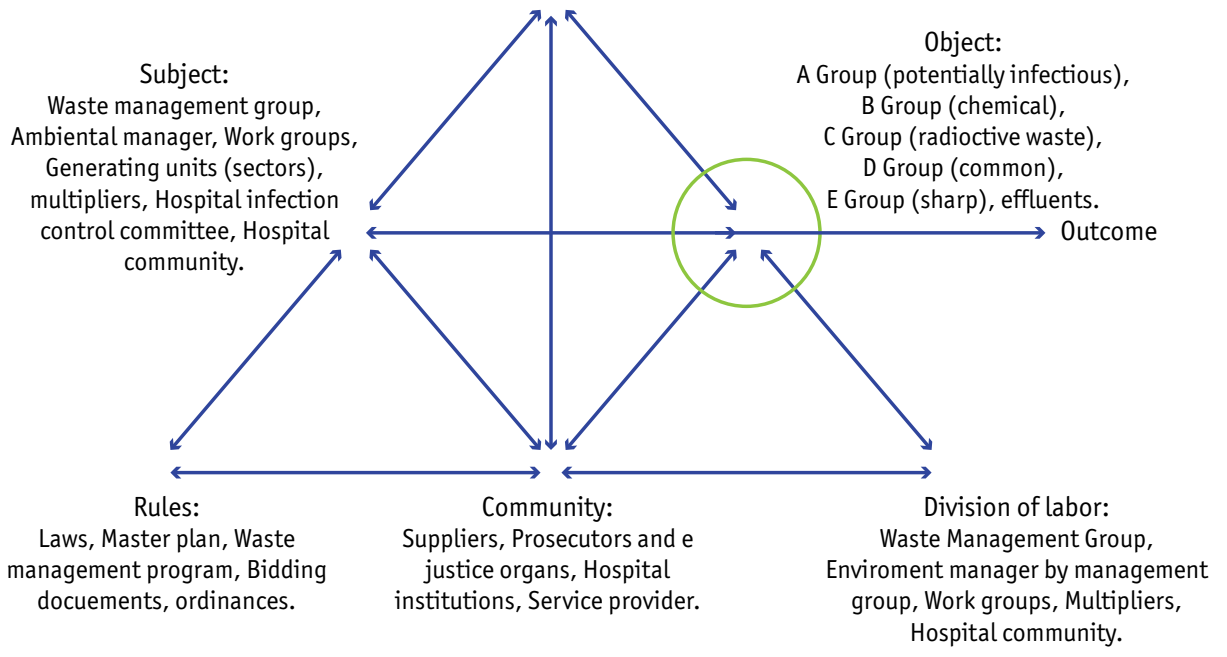

Figure 6. Future activity system

Source: Research data (2016).

Among the detail points of the future activity systems, we can mention: the pilot plan for waste management, which consisted of a service area that should count on an environmental manager, who was supposed to work in a full-time basis, 8 hours per day, in order to help the community, align with the necessary demands of proper waste management. Additionally, the group remarked that the bins present in the germ cell at that time should be counted, specifying if they were sufficient and properly identified. Also, the visual communication should be improved, which means that the bins should be visible and able to communicate the proper point for the disposal of each item.

The apprentices proposed the elaboration of an informative guide, whose content should be accessible and attentive to every item's particularity of disposal (for example, the serum bottle can have different destinations). The waste collection schedule should be planned and redefined, so the activity would be done at a different period from that of 
other activities of the sector. These were some of the ideas considered as guidelines for the future activity.

On session 11, a pilot Waste Management Group (WMG) was elaborated and the pilot group was responsible for the germ cell organization. In the beginning of session 12 , which was the last moment of the sessions' phase, the interventionist situated the group's transition from phase 4 to 5 (implementation) as of the movement required to put the implementation plan into practice. Thus, the workers were told that they would participate in two monitoring sessions, and then they would decide whether the practice of the germ cell could be expanded to other sectors or not. At this point, the interventionist warned the group that the learning experience might not result in expansion, since, practically, there was a chance for the germ cell to be inadequate to the activity's needs. After session 12 had finished, the movement in the cycle of expansive learning ceased to be monitored by the interventionist and became an autonomous process for the workers.

However, the germ cell was not implemented. The reasons for this were the problematic integration of teams and sectors, disagreements between sector coordinators, as well as cultural issues related to the organization of the hospital as a public institution. Nevertheless, the hiring of an environmental manager, expert in solid waste management, became a reality. The 20 year-experienced professional became the responsible for the waste management, and had their full-time work basis required by the workers, as well as an exclusive branch line. The participants also coordinated the elaboration, printing and distribution of an informative guide containing guidelines for the waste management. The guide was distributed during an internal event at the hospital. These two actions, namely the hiring of an expert and the informative guide-related events consist in the main concrete outcomes of the Change Laboratory in the university hospital hitherto.

\section{Discussing the learning movement}

The experience with the $C L$ method in the university hospital showed that, although the framework is prescriptive, it is not predictive. The interventionist knew what had been planned to the sessions, but neither could they (the interventionist) predict the paths the apprentices would walk through in their learning, nor know where these paths would precisely lead. The unpredicted character of the CL confirmed itself by showing that although there is prescription and planning within the $C L$ method, not always the participants follow the interventionist's instructions. 
Even though the case here presented had not focused on a detailed perspective of the interactions between the workers in the learning movement, it is possible to admit, considering the results, that the attempt to make an expansive movement is not a trajectory free from disagreement. There were moments in which the group's learning contracted and participants were not willing to continue the cycle. According to Vänninen et al. (2015), opposition is a demonstration of resistance and demonstrates the workers' capacity of agency, a movement that is also important to understand the cycle of expansive learning. In addition, the coordinator's resistance to the changes proposed by the workers illustrates these tensions.

As for the participation of the apprentices, it was noticed that hierarchical relations can disrupt the movement of expansive learning. This observation is relevant due to the experience of an operational level worker, who was intensely involved in the CL sessions' phase. She explained in session 6 that "top-level people" do not respect "lower-level people", alluding to CL workers who occupy higher education and operational positions, respectively.

The interventionist conducted the sessions in a manner similar to that of a teacher. It should be noted here that the use of the term Pedagogy does not intend to suggest that apprentices needed to be treated such as children are during the literacy process. Differently, the worker has knowledge on how to perform their work, but similar to an apprentice in a regular school, the $\mathrm{CL}$ worker needs the intervention of a more experienced professional who is able to help them to organize and broaden their learning. This is precisely the role of the interventionist, who stimulates the cognitive, cultural and social capacities of learners in the movement provided by the $\mathrm{CL}$, corroborating the concepts of ZPD and double stimulation created by Vygotsky (1978).

In addition to those reflections on the learning movement carried out in the $\mathrm{CL}$, it is important to stress that the methodology adopted by this study was created in Finland, nay, in a country whose labor reality is very different from that experienced in Brazil. For instance, whereas Finland is reported the $24^{\text {th }}$ country in the rank of the Human Development Index (based on 2014 data), Brazil stands at $75^{\text {th }}$. According to the official website of the United Nations, the HDI includes a synthetic measure of long-term development, comprising three basic dimensions: income, education and health.

Once we think about the geographical transposition of the $\mathrm{CL}$ method, in this case, from Finland to Brazil, we can return to the sociology of Guerreiro Ramos (1983). The 
author discussed the adoption, without the necessary adaptations, of management tools conceived in (and according to) the reality of developed countries, and the automatic application of them to the Brazilian reality, a developing country (a condition still true in the present, we must add).

The CHAT allows organizational learning to be understood from a multilevel perspective. It is so because the process occurs both individually and collectively and incorporates elements of the external environment by using historical movements and components of the activity as a means for learning. The relationship between learning levels reflects the ZPD concept since learners had already acquired knowledge about the activity of waste management before they agreed to participate in the interventional research. In this sense, this knowledge was "brought" and added to the CL experience (Nogueira \& Odelius, 2015).

Nonetheless, by acting as a teacher through providing double stimulation (mediating artifacts), the interventionist allowed the participants to expand their prior knowledge about the activity. As a consequence of the expansion of individual knowledge about the activity, a potential zone was built in an attempt to expand the activity itself (as a result of the workgroup's collective learning) and was materialized in the waste management plan that planned the germ cell for the activity change test. However, it is important to stress that this potential zone can include the contraction of the waste management activity, since it is not possible to predict if the workers will succeed in implementing the new activity model at the university hospital.

It is also important to highlight the role of the double stimulation in the learning process. Even though the interventionist provides learners with stimulus, the former will never be able to control the learning process or the reactions of the latter to the CL visà-vis the results facilitated by these stimuli, which are constituted as artifacts. This is the reason why the current CHAT debate is concerned with reflecting the agent nature of apprentices who participate in interventions such as that of CL. The participants are the ones who must decide on the results of the encounter through the stimuli offered by the interventionist. As an example, when the graphic representation stimulus had been offered, the participants answered, negotiated and constructed the representation of the past and present models, and continued the organization of the waste management activity as they pleased. 
Nowadays, the apprentices are implementing a new form of activity in a small space inside the hospital. It means that they are putting into practice the germ cell collectively conceived as a practical result of the $C L$ interventionist method. This has been a complex process since some participants left the expansive learning movement during the sessions' phase. In addition, the fact that the hospital is a public organization has been a challenge to test the new model, since there are specific management procedures different from that of private organizations.

Nevertheless, the outcomes of the movement concerning the expansive cycle encompassed a historical and a collective understanding of the waste management activity, from the foundation of the hospital up to the moment the research was being conducted. The analytical potential of the activity system can be confirmed since the apprentices could make connections between the past and present of the activity in order to understand the changes they consider necessary to the future waste management. Without the historicity provided by the intervention, apprentices would rarely acquire such analytical and broadened understanding of the work activity.

These findings corroborate the ones by Tkachenko e Ardichvili (2017). The authors remark that methods such as that of the $\mathrm{CL}$, although limited in terms of quantification possibilities and generalization of the research findings, can be seen as an alternative to understand different organizational contexts within processes of organizational change that involve people's engagement. On the other hand, even if the results of the intervention cannot be generalized, the problems faced when managing the waste in the university hospital may be similar to that of other hospitals, thus approximating similar organizations. In this case, although an interventionist research cannot solve all of the problems, they are certainly a light for organizations to think about alternatives. The interventionist methods of the CHAT, such as the CL, are seen as a possibility for action and change in organizations.

\section{Final remarks}

This study aimed for understanding how the learning movement was experienced by a group of workers throughout an interventionist research wherein a Change Laboratory was applied. The study took place at a Brazilian university hospital and was based on the historical-cultural activity theory. According to this kind of research, besides conducting a field research, providing data collection and analyzing them, it is necessary to change 
a given reality. In this sense, the final product corroborated the results expected for a Change Laboratory, as Virkkunen \& Newnham (2015, p. 267) posit:

(1) "knowledge and understanding towards challenges and possibilities for developing the activity": historical understanding of the waste management, its strengths and weaknesses;

(2) "collective and individual transformative agency": the hospital workers could take the responsibility for proposing and developing new solutions by themselves, and refuse this responsibility anytime;

(3) "new concepts formation, new tools and new organizational schemes": the consolidation of a pilot plan for waste management, constructed by the workers, along with the hiring of an environment manager professional supposed to work in a full-time basis (as the workgroup had previously requested), were possible due to the workers' engagement with the learning movement;

(4) "change and development of both activity and individuals": acknowledgment that the learning constructed by the $\mathrm{CL}$ participants worked as individual learning, also with potential for collective learning, besides the existent barriers that may prevent this. To illustrate, one of the participants mentioned, during a post-CL interview, that even after the conclusion of the Change Laboratory "course", she continues to share with her co-workers, on a daily basis, what she has learnt about waste management.

The learning based on the CHAT allows the understanding that, besides pointing out problems, subjects in organizations are full of possibilities and should not be considered only as objects of study. The attempt to rethink the work of those who deal with waste management at a hospital made possible the existence of a learning by reflection on the three moments of history: in movement, by recovering the collective memory and to build the present. In this sense, some questions started to be problematized and can be revisited in future studies, which can approach the development of the case studied here.

In addition, it is important to mention that some activities can be interpreted as simple on the surface, such as the waste management one - which apparently involves only operational aspects -, but in fact they can be as complex as any other. The difficulties faced during the development of the $C L$ to implement the changes on the waste manage- 
ment can illustrate such complexity. Bearing this in mind, the management of people involved in a given work activity must be understood beyond techniques and tools that are part of such, because the delimitation to these procedures and materials are not always enough to guarantee the full exercise of this activity.

Thus, we can posit that the recovery of the history of a work activity was a learning practice able to make the apprentices "see" the opportunity they had to follow the legal requirements set for the activity, that is, they exercised their resilience capacity of the past. This recovery also allowed apprentices to realize the potential of the present, since they noticed that the waste management in unstable concerning its norms and regulations. Thus, we could notice how the history told by the people who experienced the activity in the past could help workers in constructing their idea about the present. Additionally, it was able to help with the formulation of a new model, lacking a fixed understanding of "how this should be done", since the nature of the object (waste management) is constantly under change given the normative pressures, but in a resilient perspective.

The contribution of this study results from the reflection related to the ontological place wherein the cultural-historical theory recognizes that a historical trajectory is material and concrete, but also mediated by the subjectivities of the individuals in interaction. In this sense, learning is understood as a social and cultural phenomenon, and not just a biological or cognitive one (Sannino, Engeström, \& Lahikainen, 2016).

In the field of reflexivity, the exercise of $\mathrm{CL}$ is revealed as an inclusive and democratic experience in organizations, since the historical narrative is collectively constructed under the workers' writing, who, at least in the $\mathrm{CL}$ environment, are not distinguished by status or position they occupy inside the organization.

Objectively, although the CL method had been applied from a management or structural perspective, it did not provoke a great transformation in the waste management activity of the hospital. However, the partial results obtained by the monitoring sessions and the eight interviews conducted showed that the historicity present in the experiences lived by the workers in the $\mathrm{CL}$ allowed them to be aware of themselves, as well as of the importance of their work, either from a functional or a social viewpoint.

Therefore, the change of a given activity to a model that is more developed does not work as a "cake recipe", as pondered by a worker in an interview, referring to the dynamics of the learning in the $\mathrm{CL}$. In this sense, the understanding of that activity from 
a genetic-historical perspective allows the participants to become more resilient concerning their ability to size the several advances and setbacks in the waste management throughout its history. In sum, it refuses the affirmation that organizational change is an ahistorical, linear process, identical in different contexts.

As a final reflection, Van Maanen (1979) compares the construction of a qualitative research to the process of a map elaboration. By the end of the research, the reader is placed before a constructed map. This map would be the representation of the territory, which, in this study, is the learning movement constructed by the workers in the $C L$ at the hospital. Being a representation, it is unable to encompass, accurately, all the reality of this territory. So, let the cartographers come, they who are willing to know the cake, and not "just" the recipe...

\section{References}

Ahonen, H., Engestrm, Y., \& Virkkunen, J. (2000). Knowledge management - The second generation: Creating competencies within and between work communities in the competence laboratory. In Y. Malhotra (ed.), Knowledge Management and Virtual Organizations (pp. 282-305). Hershey USA: Idea Group Publishing.

Antonello, C., \& Godoy, A. (2011). Aprendizagem organizacional e as raízes de sua polissemia. In: C. Antonello \& A. Godoy (orgs.), Aprendizagem organizacional no Brasil (pp. 31-50). Porto Alegre: Bookman.

Braga, E. S. dos. (2010). Lev Vigotski - Principais teses: a constituição social do desenvolvimento. Revista Educação, São Paulo, 2(154), 20-29.

Cassandre, M. (2012). Metodologias intervencionistas na perspectiva da teoria da atividade histórico-cultural: um aporte metodológico para estudos organizacionais. Tese de Doutorado em Administração. Curitiba: Universidade Positivo.

Cellard, A. (2012). A análise documental. In: J. Poupart, J. Deslauriers, L. Groulx, A. Laperriere, R. Mayer, \& A. Pires. A pesquisa qualitativa: enfoques epistemológicos e metodológicos (pp. 295-316). Petrópolis: Vozes.

Cole, M. (1996). Cultural psychology: A once and future discipline. Cambridge: Belknap Press. Engeström, Y. (1987). Learning by expanding. Helsinki: Orienta-Konsultit Ou.

Engeström, Y. (1999). Activity theory and individual and social transformation. In: Engeström, Y., Miettinen, R., \& Punamäki, R. (eds.), Perspectives on activity theory (pp. 19-38). Cambridge: University Press. 
Engeström, Y. (2000). From individual action to collective activity and back: developmental work research as an interventionist methodology. In Luff, P., Hindmarsh, J., \& Heath, C. (eds.), Workplace studies (pp. 150-166). Cambridge: Cambridge University Press.

Engeström, Y. (2001). Expansive learning at work: Toward an activity theoretical reconceptualization. Journal of Education and Work, 14(1), 133-156.

Engeström, Y. (2014). Learning by expanding. 2nd. ed. Cambridge: Cambridge University Press.

Engeström, Y., \& Sannino, A. (2010). Studies of expansive learning: Foundations, findings and future challenges. Educational Research Review, 5(1), 1-24.

Engeström, Y., \& Sannino, A. (2011). Discursive manifestations of contradictions in organizational change efforts: A methodological framework. Journal of Organizational Change Management, 24(3), 368-387.

Engeström, Y., \& Sannino, A. (2016). Expansive learning on the move: Insights from ongoing research. Infancia y Aprendizaje, 39(3), 401-435.

Engeström, Y., Virkkunen, J., Helle, M., Pihlaja, J., \& Poikela, R. (1996). Change Laboratory as a tool for transforming work, Lifelong Learning in Europe, 1(2).

Garcez, A., Duarte, R., \& Eisenberg, Z. (2011). Produção e análise de videogravações em pesquisas qualitativas. Educação e Pesquisa, 37(2), 249-262.

Grey, C. (2004). 0 Fetiche da Mudança. RAE-Revista de Administração de Empresas, 44(1), 10-25.

Haapasaari, A., \& Kerosuo, H. (2015). Transformative agency: The challenges of sustainability in a long chain of double stimulation. Learning, Culture and Social Interaction, 4, 37-47.

Haapasaari, A., Engeström, Y., \& Kerosuo, H. (2018). From initiatives to employee-driven innovations. European Journal of Innovation Management, 21(2), 206-226.

Hill, R., Capper, P., Wilson, K., Whatman, R., \& Wong, K. (2007). Workplace learning in the New Zealand apple industry network: A new co-design method for government 'practice making. Journal of Workplace Learning, 19(6), 359-376.

Kajamaa, A. \& Schultz, K. (2017). From the abstract to the concrete: Implementation of an innovative tool in home care. Health Services Management Research Journal. Published online before print August, 17, 2017.

Levitin, K., \& Davydov, V. (1982). One is not born a personality: Profiles of Soviet education psychologists. Moscow: Progress Publishers.

Loizos, P. (2008). Vídeo, filme e fotografias como documentos de pesquisa. In Bauer, M., \& Gaskell, G. (eds.), Pesquisa qualitativa com texto, imagem e som: um manual prático (pp. 137-155). Petrópolis: Vozes.

Meshcheryakov, B. G. (2007). Terminology in Vygotsky's writings. In: Daniels, H.; Cole, M.; Wertsch, J. V. (Eds.). The Cambridge companion to Vygotsky (pp. 155-177). Cambridge: University Press. 
Nogueira, R. A., \& Odelius, C. C. (2015). Desafios da pesquisa em aprendizagem organizacional. Cadernos EBAPE.BR, 13(1), 83-102.

Querol, M. A. P., Cassandre, M. P., \& Bulgacov, Y. L. M. (2014). Teoria da Atividade: contribuições conceituais e metodológicas para o estudo da aprendizagem organizacional. Gestão \& Produção, 21(2), 405-416.

Querol, M. A. P., Jackson Filho, J. M, \& Cassandre, M. P. (2011). Change Laboratory: uma proposta metodológica para pesquisa e desenvolvimento da Aprendizagem Organizacional. Administração: ensino e pesquisa, 12(4), 609-640.

Ramos, A. G. (1983). Administração e contexto brasileiro: esboço de uma teoria geral da Administração. Rio de Janeiro: FGV.

Rantavuori, J., Engeström, Y., \& Lipponen, L. (2016). Learning actions, objects and types of interaction: A methodological analysis of expansive learning among pre-service teachers. Frontline Learning Research, 4(3), 1-27.

Sannino, A. (2011). Activity theory as an activist and interventionist theory. Theory \& Psychology, 21(5), 571-597.

Sannino, A., Daniels, H., \& Gutiérrez, K. (2009). Activity theory: between historical engagement and future-making practice. In Sannino, A., et al. (eds.), Learning and expanding with activity theory (pp. 1-16). Cambridge: Cambridge University Press.

Sannino, A., Engeström, Y., \& Lahikainen, J. (2016). The dialectics of authoring expansive learning: Tracing the long tail of a change laboratory. Journal of Workplace Learning, 28(4), 245-262.

Sannino, A., Engeström, Y., \& Lemos, M. (2016). Formative interventions for expansive learning and transformative agency. Journal of the Learning Sciences, 25(4), 599-633.

Santos, V. (2017). Intervenção Trans/Formativa: construindo e implementando uma ferramenta para a Aprendizagem Organizacional baseada na Teoria da Atividade Histórico-Cultural e na Psicologia da Libertação. Master's dissertation in Administration. Maringá: Universidade Estadual de Maringá.

Tkachenko, 0., \& Ardichvili, A. (2017). Cultural-historical activity theory's relevance to HRD: A review and application. Human Resource Development Review, 16(2), 135-157.

Van Maanen, J. (1979). Reclaiming qualitative methods for organizational research: a preface. Administrative Science Quarterly, 24(4), 520-526.

Vänninen, I., Pereira-Querol, M., \& Engeström, Y. (2015). Generating transformative agency among horticultural producers: an activity theoretical approach to transforming integrated pest Management. Agricultural Systems, 139, 38-49.

Virkkunen, J., \& Newnham, D. S. (2015). 0 laboratório de mudança: uma ferramenta de desenvolvimento colaborativo para o trabalho e educação. Belo Horizonte: Fabrefactum. 
Virkkunen, J., \& Tenhunen, E. (2010). Finding a Concept that Integrates Specialists' KnowHow - The Case of Special School for Handicapped and Neurologically Ill Children. Actio - International Journal of Human Activity Theory 3, 1-23.

Vygotsky, L. (1978). Interaction between learning and development. In Cole, M. et al. Mind in society (pp. 79-91). Cambridge: Cambridge University Press.

Licencia Creative Commons CC BY 4.0 
